\title{
Nerve growth factor (NGF) expression in correlation with severity of pruritus in cirrhotic patients
}

\author{
by \\ Essam El-din Abd El-Aziz Nada ${ }^{1}$, HananAbd El RadyMetwallyAssaf ${ }^{1}$, RehamEzz El \\ Dawla El Sharkawi ${ }^{1}$, Amr MohamedZagloul ${ }^{2}$,Marwa Mohamed Abd El \\ Meged $^{1}$,Mahmoud RezkAbd El Wahed Hussein ${ }^{3}$ \&Asmaa Mahmoud Ahmed ${ }^{3}$. \\ ${ }^{1}$ Department of Dermatology, Venereology and Andrology, Sohag Faculty of Medicine, Sohag University, ${ }^{2}$ \\ Department of Tropical Medicine and Gastroenterology, Sohag Faculty of Medicine, Sohag University ${ }^{3}$ \\ Department of pathology, Assuit Faculty of Medicine, Assuit University
}

\begin{abstract}
Background:Hepatic pruritus is a very common symptom among different chronic liver diseases, particularly in those related to cholestasis. Its prevalence is variable among liver diseases, ranging from 5\% in chronic hepatitis $\mathrm{C}$ virus infection to $70 \%$ in primary biliary cirrhosis. Its etiopathogenesis remains poorly understood.Nerve growth factor (NGF) is a member of neurotrophins. many studies clearly demonstrate their role in pruritus. Nerve growth factor (NGF) is overexpressed in prurigonodularis and its therapeutic administration is pruritogenic. In atopic dermatitis, NGF is released by keratinocytes, mast cells and fibroblasts and plasma levels of NGF are also elevated and correlate with disease activity.This study examines the hypothesis that expression of NGF protein is altered in cirrhotic patients with pruritus.
\end{abstract}

Patients and Methods: To test our hypothesis, we examined the expression patterns of NGF protein in cirrhotic patients with pruritus, cirrhotic patients without pruritus and corresponding healthy (control). skin biopsies (20 specimens each) were evaluated using immunoperoxidase staining techniques.

Results: We found variations between the skins of cirrhotic patients with and without pruritus and healthy skin. In healthy skin, the expression of NGF protein was strong (basal cell keratinocytes), moderate (spinouslayer), and weak or abscent (granular cell layer). In contrast, marked expression of NGF protein was observed in all layers of skin (total NGF epidermis and dermis) incirrhotic patients with pruritus in comparison with cirrhotic patients without pruritus and healthy control and this was statistically significant. NGF protein expression was strong (basal cell keratinocytes), moderate (spinous layer), and weak or abscent (granular cell layer). The expression of NGF protein was strong in the adnexal structures.

Conclusions: We report, for the first time, increased expression of NGF protein in the epidermal keratinocytes of cirrhotic patients with pruritus skin. Our findings suggest possible roles for this protienin pathophysiology of hepatic pruritus. The clinical ramifications of these observations mandate further investigations. 


\section{Introduction}

Pruritus is a common symptom in hepatobiliary disorders, particularly in those related to cholestasis (1). Its prevalence is variable among liver diseases, ranging from $5 \%$ in chronic hepatitis $\mathrm{C}$ virus infection to $70 \%$ in primary biliary cirrhosis. there is no correlation between severity of liver disorders and cholestasis and pruritus intensity(2).Despite the major advances in the last 15 years in the study of pruritus, its etiopathogenesis in the cholestasis remains poorly understood $(\mathbf{3}, \mathbf{4})$. There are many theories concerning mechanisms and chemical mediators(5).

Pruritic skin diseases are associated with increased production and release of cytokines, neuropeptides and neurotrophins which possibly leading to the exacerbation of pruritus (6).Neurotrophins (NTs) belong to a group of functionally and structurally related proteins the neurotrophic factors' family that were first identified as promoters for neuronal survival. It was demonstrated that they regulate many aspects of neuronal development and function, like synapse formation and synaptic plasticity (7). There are four NTs are expressed in mammals: NGF, BDNF, NT-3 NT-4. They play an essential role in cellular interactions, in controlling cell survival and differentiation (8). Neurogenic Inflammation is a physiological mechanism that could be involved in pruritus (9). It is triggered by the activation of primary sensory neurons with a subsequent release of inflammatory neuromediators, resulting in a neurally mediated immune inflammation. Neuromediators are mainly released from neurons. Immune and/or structural cells are secondary sources of these mediators during immune inflammation (10). Local inflammatory mechanisms may induce pruritus in many dermatoses. Mild-to-severe pruritus accompanies numerous inflammatory skin disorders including atopic dermatitis, eczema, psoriasis, or lichen planus (11). So, it is speculated that NGF may contribute to the pathophysiology of hepatic pruritis and may correlate to disease severity. Accordingly, substances targeting NGF could be a future option for its treatment preventing the pruritus from becoming chronic.

Aim of the work:toevaluate the expression pattern of NGF protein in cirrhotic patients with pruritus, cirrhotic patients without pruritus and corresponding healthy (control) and its correlation with severity of pruritus in cirrhotic patients.

\section{Patients and methods}

This study was carried out at the Department of Dermatology, Venereology and Andrology jointly with Department of Gastroenterology and Tropical Medicine at Sohag University Hospitals Egypt. The study was approved by the institutional Ethics and Research Committee of Faculty of Medicine, Sohag University, Egypt. An informed consent was obtained from all participants after full explanation of the procedure. The study included 40 patients $(20$ were cirrhotic with pruritus and 20 were cirrhotic without pruritus) as well as from 20 age and sex matched healthy volunteers between January 2015 to December 2016. Patients with history of associated endocrinal disorders e.g; diabetes mellitus, thyroid disease or chronic renal illness andPatients presented with other itchy or nonitchy dermatoseswere excluded from the study. The severity of itching in cirrhotic patients with pruritus was 
assessed with the 5-D itch score. It is a brief but multidimensional questionnaire. The five dimensions are degree, duration, direction, disability and distribution (Elman et al, 2010 )

Histopathological evaluation:Punch skin biopsies $(4 \mathrm{~mm})$ each were obtained from cirrhotic patients with pruritus (20) and cirrhotic patients without pruritus (20) as well as from age and sex matched healthy volunteers (20). The formalin fixedparaffin embedded tissues were processed for routine histology (Hematoxylin and eosin stains) and special (Giemsa stain) as well as immunohistochemical stains at the Department of Pathology, Faculty of Medicine, Assuit University Hospitals.

\section{Immunohistochemical evaluation}

Immunostaining was performed on four microns thick formalin fixedparaffin embedded tissue sections using primary antibodies targeting NGF and TrK-A proteins. Avidin Biotin immunoperoxidase staining technique was used. The expression pattern of NGF and TrKA of the three groups of specimens were evaluated and reported as staining intensity. Corresponding sections stained by $H \& E$ were examined side by side with immunostained sections.
In each case, the entire section was histologically examined to detect the site and distribution of antibody positivity. Then close up magnification was used to evaluate the immunostains. NGF and TrKA proteins expression were considered positive if cytoplasmic staining pattern was detected within the cells. The staining intensity was scored as follow: 0 (no staining), 1 (weak), 2 (moderate) and 3 (strong) (Hussein et al, 2007,2008,

2016).

\section{Statistical analysis:}

Data was analyzed using SPSS computer program version 22.0. Quantitative data was expressed as means \pm standard deviation, median and range. Qualitative data was expressed as number and percentage. The data were tested for normality using Shapiro-Wilk test. The nonparametric Mann-Whitney test, Kruskal-Wallis test and Spearman's correlation were used for data which wasn't normally distributed.One-Way ANOVA test and Pearson's correlation were used for normally distributed data. Chi-Square test was used for comparison between qualitative variables. A 5\% level was chosen as a level of significance in all statistical tests used in the study.

\section{Results}

The ages of cirrhotic patients with pruritus group ranged from (35- 67 years) with mean \pm SD $(52.7 \pm 9.1)$, in cirrhotic patients with pruritus ranged from (47- 67 years) with mean $\pm \mathrm{SD}(55 \pm 5.3)$ and in the control group ranged from (37- 60 years) with mean $\pm \mathrm{SD}(51 \pm 7.3)$. There was no statistical significant difference between the studied groups as regard age.The total number of males in the studied groups is 31(9 cirrhotic patients with pruritus, 11 cirrhotic patients without pruritus and 11 control group).Total number of females in the studied groups is 29 (11 cirrhotic patients with pruritus, 9 cirrhotic patients without pruritus and 9 control group). There was no statistical significant difference between the studied groups as regard sex.There was no statistical significant difference between the studied groups as regard other sociodemographic data including: residence, marital status and special habits. Cirrhotic Patients with pruritus (group 2) can be divided according to severity of pruritus into: mild (30\%), moderate (35\%), severe (20\%) and very severe $(15 \%)$. 
In the epidermis and as well as among the dermal adnexal structures. The expression (staining intensity) was higher in all compartments of the integument (epidermis and dermis) in the pruritus group as compared to the expression values both in nonpruritus and healthy control skins. A summary of these results are shown in Table (1), and Figure $(1,2,3)$.

There was positive correlation between NGF protein expression and severity of pruritus in cirrhotic patients with pruritus (group 1) $(\mathrm{r}=0.876, \mathrm{p}$ value $<0.001$ ). Table (2,3), figure (4)

Table (1): comparison between the three studied groups regarding NGF expression:

\begin{tabular}{|c|c|c|c|c|}
\hline Parameter & $\begin{array}{c}\text { Group 1 } \\
\text { (with pruritus) } \\
(\mathbf{N}=\mathbf{2 0}) \\
\end{array}$ & $\begin{array}{c}\text { Group } 2 \\
\text { (without pruritus) } \\
(\mathrm{N}=\mathbf{2 0})\end{array}$ & $\begin{array}{c}\text { Group } 3 \\
\text { (Control group) } \\
(\mathbf{N}=\mathbf{2 0}) \\
\end{array}$ & P-value \\
\hline $\begin{array}{l}\text { Spinous layer } \\
\text { Mean } \pm \text { S.D. } \\
\text { Median (Range) }\end{array}$ & $\begin{array}{r}0.9 \pm 0.6 \\
1(0-2) \\
\end{array}$ & $\begin{array}{c}0.7 \pm 0.5 \\
1(0-1) \\
\end{array}$ & $\begin{array}{c}0.8 \pm 0.4 \\
1(0-1)\end{array}$ & 0.374 \\
\hline $\begin{array}{c}\text { Basal cell } \\
\text { Mean } \pm \text { S.D. } \\
\text { Median (Range) }\end{array}$ & $\begin{array}{c}1.9 \pm 0.8 \\
2(1-3)\end{array}$ & $\begin{array}{c}1.3 \pm 0.4 \\
1(1-2)\end{array}$ & $\begin{array}{c}0.8 \pm 0.4 \\
1(0-1)\end{array}$ & $<0.001 *$ \\
\hline $\begin{array}{c}\text { Total epidermis } \\
\text { Mean } \pm \text { S.D. } \\
\text { Median(Range) }\end{array}$ & $\begin{array}{c}2.8 \pm 1.1 \\
3(1-4)\end{array}$ & $\begin{array}{r}1.9 \pm 0.7 \\
2(1-3)\end{array}$ & $\begin{array}{r}1.6 \pm 0.8 \\
2(0-2)\end{array}$ & $0.002 *$ \\
\hline $\begin{array}{c}\text { Nerves } \\
\text { Mean } \pm \text { S.D. } \\
\text { Median (Range) }\end{array}$ & $\begin{array}{l}0.4 \pm 0.5 \\
0(0-1)\end{array}$ & $\begin{array}{l}0.4 \pm 0.5 \\
0(0-1)\end{array}$ & $\begin{array}{l}0.3 \pm 0.5 \\
0(0-1)\end{array}$ & 0.806 \\
\hline $\begin{array}{c}\text { Fibroblasts } \\
\text { Mean } \pm \text { S.D. } \\
\text { Median (Range) }\end{array}$ & $\begin{array}{l}1.2 \pm 0.5 \\
1(0-2)\end{array}$ & $\begin{array}{l}0.9 \pm 0.5 \\
1(0-2)\end{array}$ & $\begin{array}{l}0.9 \pm 0.6 \\
1(0-2)\end{array}$ & 0.166 \\
\hline $\begin{array}{c}\text { Hair follicle } \\
\text { Mean } \pm \text { S.D. } \\
\text { Median (Range) }\end{array}$ & $\begin{array}{l}0.7 \pm 0.7 \\
1(0-2)\end{array}$ & $\begin{array}{l}0.6 \pm 0.6 \\
1(0-2)\end{array}$ & $\begin{array}{c}0.5 \pm 0.5 \\
0.5(0-1)\end{array}$ & 0.741 \\
\hline $\begin{array}{c}\text { Eccrine } \\
\text { Mean } \pm \text { S.D. } \\
\text { Median (Range) }\end{array}$ & $\begin{array}{l}0.9 \pm 0.9 \\
1(0-2)\end{array}$ & $\begin{array}{c}0.5 \pm 0.5 \\
0.5(0-1)\end{array}$ & $\begin{array}{c}0.5 \pm 0.5 \\
0.5(0-1)\end{array}$ & 0.380 \\
\hline $\begin{array}{c}\text { Total dermis } \\
\text { Mean } \pm \text { S.D. } \\
\text { Median (Range) }\end{array}$ & $\begin{array}{l}3.1 \pm 1.8 \\
3.5(0-6)\end{array}$ & $\begin{array}{c}2.5 \pm 1.4 \\
3(0-4) \\
\end{array}$ & $\begin{array}{c}2.2 \pm 1.3 \\
2(1-4)\end{array}$ & 0.192 \\
\hline $\begin{array}{c}\text { Total NGF } \\
\text { (epidermis+dermis) } \\
\text { Mean } \pm \text { S.D. } \\
\text { Median (Range) } \\
\end{array}$ & $\begin{array}{c}5.9 \pm 2.7 \\
6.5(1-10)\end{array}$ & $\begin{array}{c}4.4 \pm 1.8 \\
5(1-7)\end{array}$ & $\begin{array}{l}3.8 \pm 1.6 \\
3(2-6)\end{array}$ & 0.016* \\
\hline
\end{tabular}

P-value was calculated by Kruskal Wallis test * statistically significant 
SOHAG MEDICAL JOURNAL Vol. 22 No.1 Jan 2018
Nerve growth factor (NGF) expression in correlation Marwa Mohamed Abd El Meged

Table (2) : NGF expression according to disease severity in cirrhotic patients with pruritus (group 1):

\begin{tabular}{|c|c|c|c|c|c|}
\hline Parameter & $\begin{array}{c}\text { Mild } \\
(N=6)\end{array}$ & $\begin{array}{c}\text { Moderate } \\
(\mathrm{N}=7)\end{array}$ & $\begin{array}{l}\text { Severe } \\
(N=4)\end{array}$ & $\begin{array}{c}\text { Very severe } \\
(\mathbf{N}=\mathbf{3})\end{array}$ & P-value \\
\hline $\begin{array}{c}\text { Spinous layer } \\
\text { Mean } \pm \text { S.D. } \\
\text { Median (Range) }\end{array}$ & $\begin{array}{r}0.5 \pm 0.5 \\
0.5(0-1) \\
\end{array}$ & $\begin{array}{r}1 \pm 0.6 \\
1(0-2) \\
\end{array}$ & $\begin{array}{l}1.3 \pm 0.5 \\
3(2-3) \\
\end{array}$ & $\begin{array}{c}1 \pm 1 \\
1(0-2)\end{array}$ & 0.280 \\
\hline $\begin{array}{c}\text { Basal cell } \\
\text { Mean } \pm \text { S.D. } \\
\text { Median (Range) }\end{array}$ & $\begin{array}{c}1 \pm 0 \\
1(1-1)\end{array}$ & $\begin{array}{l}1.9 \pm 0.4 \\
2(1-2)\end{array}$ & $\begin{array}{l}2.8 \pm 0.5 \\
3(2-3)\end{array}$ & $\begin{array}{l}2.7 \pm 0.6 \\
3(2-3)\end{array}$ & $0.001 *$ \\
\hline $\begin{array}{c}\text { Epidermis } \\
\text { Mean } \pm \text { S.D. } \\
\text { Median (Range) } \\
\end{array}$ & $\begin{array}{r}1.5 \pm 0.5 \\
1.5(1-2) \\
\end{array}$ & $\begin{array}{c}2.9 \pm 0.7 \\
3(2-4) \\
\end{array}$ & $\begin{array}{r}4 \pm 0 \\
4(4-4) \\
\end{array}$ & $\begin{array}{c}3.7 \pm 0.6 \\
4(3-4) \\
\end{array}$ & $0.002 *$ \\
\hline $\begin{array}{c}\text { Nerves } \\
\text { Mean } \pm \text { S.D. } \\
\text { Median (Range) }\end{array}$ & $\begin{array}{c}0.17 \pm 0.4 \\
0(0-1)\end{array}$ & $\begin{array}{c}0.43 \pm 0.5 \\
0(0-1)\end{array}$ & $\begin{array}{c}0.5 \pm 0.6 \\
0.5(0-1)\end{array}$ & $\begin{array}{l}0.3 \pm 0.6 \\
0(0-1)\end{array}$ & 0.705 \\
\hline $\begin{array}{c}\text { Fibroblasts } \\
\text { Mean } \pm \text { S.D. } \\
\text { Median (Range) }\end{array}$ & $\begin{array}{l}0.8 \pm 0.4 \\
1(0-1) \\
\end{array}$ & $\begin{array}{l}1.3 \pm 0.5 \\
1(1-2)\end{array}$ & $\begin{array}{c}1.5 \pm 0.6 \\
1.5(1-2)\end{array}$ & $\begin{array}{c}1.33 \pm 0.6 \\
1(1-2)\end{array}$ & 0.212 \\
\hline $\begin{array}{c}\text { Hair follicle } \\
\text { Mean } \pm \text { S.D. } \\
\text { Median (Range) }\end{array}$ & $\begin{array}{l}0.3 \pm 0.5 \\
0(0-1)\end{array}$ & $\begin{array}{l}0.6 \pm 0.5 \\
1(0-1)\end{array}$ & $\begin{array}{c}1 \pm 0.8 \\
1(0-2)\end{array}$ & $\begin{array}{c}1.33 \pm 1.16 \\
2(0-2)\end{array}$ & 0.293 \\
\hline $\begin{array}{c}\text { Eccrine gland } \\
\text { Mean } \pm \text { S.D. } \\
\text { Median (Range) }\end{array}$ & $\begin{array}{c}\mathbf{0} \pm \mathbf{0} \\
\mathbf{0}(\mathbf{0}-\mathbf{0})\end{array}$ & $\begin{array}{l}0.9 \pm 0.7 \\
1(0-2)\end{array}$ & $\begin{array}{c}1.3 \pm 0.9 \\
1.5(0-2)\end{array}$ & $\begin{array}{c}2 \pm 0 \\
2(2-2)\end{array}$ & $0.009 *$ \\
\hline $\begin{array}{c}\text { Dermis } \\
\text { Mean } \pm \text { S.D. } \\
\text { Median (Range) }\end{array}$ & $\begin{array}{c}1.3 \pm 1.03 \\
1(0-3)\end{array}$ & $\begin{array}{c}3.1 \pm 1.6 \\
4(1-5)\end{array}$ & $\begin{array}{c}4.3 \pm 0.9 \\
4.5(3-5)\end{array}$ & $\begin{array}{c}5 \pm 1 \\
5(4-6)\end{array}$ & $0.012 * *$ \\
\hline $\begin{array}{c}\text { Total NGF } \\
\text { (epidermis+dermis) } \\
\text { Mean } \pm \text { S.D. } \\
\text { Median (Range) }\end{array}$ & $\begin{array}{l}2.8 \pm 1.2 \\
3(1-4)\end{array}$ & $\begin{array}{r}6 \pm 1.9 \\
6(3-8)\end{array}$ & $\begin{array}{r}8.3 \pm 0.9 \\
8.5(7-9)\end{array}$ & $\begin{array}{r}8.7 \pm 1.5 \\
9(7-10)\end{array}$ & $<0.001 * *$ \\
\hline
\end{tabular}

* P-value was calculated by Kruskal Wallis test** P-value was calculated by One-way ANOVA Test

Table(3): Correlation between severity score and NGF expression in patients with pruritus (group 1):

\begin{tabular}{|c|c|c|}
\hline Parameter & \multicolumn{2}{|c|}{ Severity score } \\
\cline { 2 - 3 } & $\mathbf{r}$ & P-value \\
\hline NGF expression & $\mathbf{0 . 8 7 6}$ & $<0.001 *$ \\
\hline
\end{tabular}

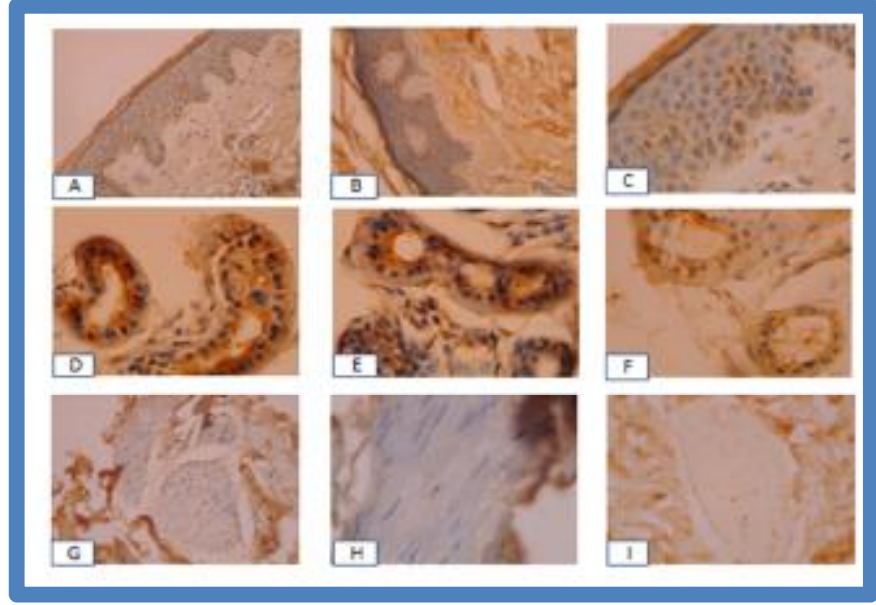


Figure ( 1) : Immunohistochemical expression of NGF protein in cirrhotic patients with pruritus.

Strong positive cytoplasmic immunoreactivity seen in: In the epidermis (A 200x-B 200x-C 400x)In the eccrine glands (D 400x-E 400x-F 400x), Hypertrophied nerves (G 200x-H 400x-I 200x

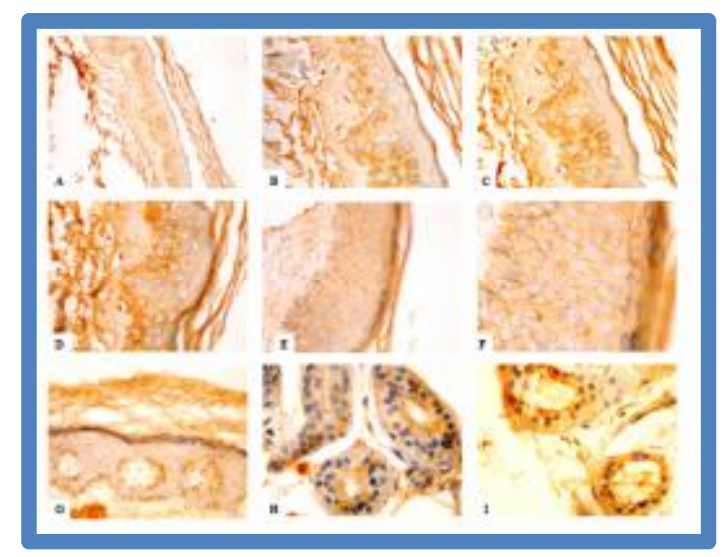

Figure ( 2):Immunohistochemical expression of NGF protein in cirrhotic patients without pruritus. Positive weak to moderate cytoplasmic immunoreactivity seen in: In the epidermis (A 200x -B,C,D 400x -E 200x -F 400x -G 200x)In the eccrine glands (H,I 400x)

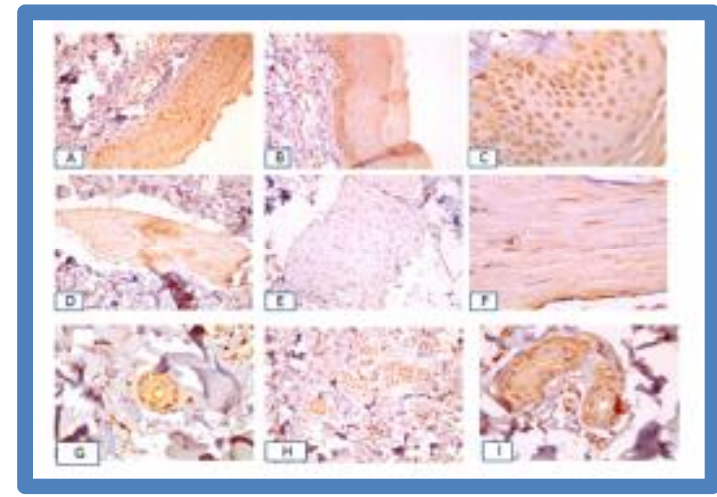

Figure ( 3):Immunohistochemical expression of NGF protein in healthy skin and positive control. Positive weak and moderate cytoplasmic immunoreactivity seen in:

Epidermis (A 200x, B 200x, C 400x)

Nerves (D 200x, E , F 400x)

Eccrine glands (G 200x, H 100x, I 200)

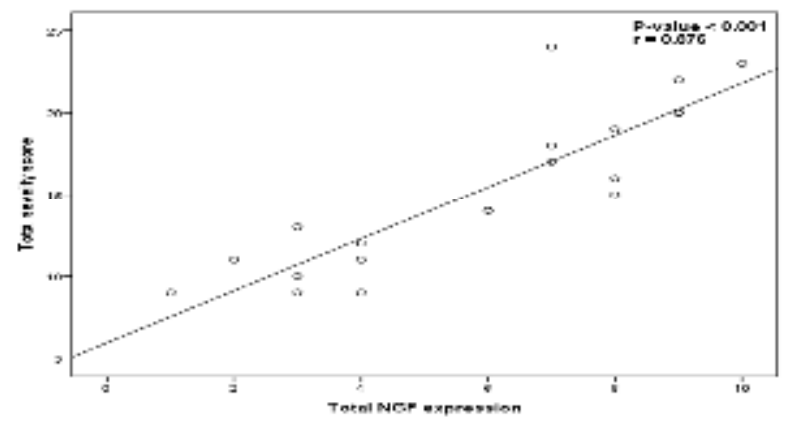

Figure (4):Correlation between severity score and NGF expression in patients with pruritus (group 1). 


\section{Discussion}

Here, we hypothesized that "NGF protein expression is altered in the skin of cirrhotic patients with pruritus". To fill this existing gap in literature and to test our hypothesis, we carried out this investigation using immunohistochemical technique. To the best of our knowledge, there were no previous studies that investigated the expression pattern of NGF in cirrhotic patients with pruritus. The present case-control hospital based study highlights for the first time the expression pattern NGF and its receptor in cirrhotic patients with pruritus .

Our study clearly demonstrated the following observations:

(i) Strong NGF protein expression in the healthy skins. (ii) Higher NGF protein expression value in the skinof cirrhotic patients as compared to the expression values both in non-pruritus and healthy controls.(iii) There is a positive correlation between NGF protein expression and severity of pruritus in cirrhotic patients.

In this study, in the epidermis, the expression value of NGF protein is higher in the basal cell keratinocytes, moderate to strong in the spinous cell layer and decrease gradually towards the granular cell layer .These findings in agreement with Adly et al (2006). Those group examined for the first time, the immunostaining values of both NGF protein in fifty normal human scalp skin biopsy specimens by immunofluorescent and immunoperoxidase method (12). They reported that The NGF protein immunoreactivities were positive in normal human scalp skins. Also, protein immunoreactivities were found in the epidermal keratinocytes, melanocytes, sweat, and sebaceous glands (12). Also Duo et al and his colleagues (2006)observed immunoreactivity both in the epidermis of normal and uninvolved skin in comparison with the skins of patients with atopic dermatitis. Weak NGF-immunoreactive (IR) cells were seen in the epidermal basal layer, but there were a few stronger IR epidermal cells in the basal and spinal layers (13).

In the dermis, we observed NGF protein expression in the dermal adnexal structures in normal healthy skins including: the eccrine glands, dermal nerve endings, lymphocytes, fibroblasts and endothelial cells. In agreement with thisDuo et al.(2006) observed NGF immunoreactivity in the upper dermis (13) In the current study, the expression pattern of NGF protein in the skin of cirrhotic patients with pruritus in comparison to non-pruritus and normal healthy skin.was higher in both the epidermis and dermal adnexal structures in cirrhotic patients with pruritus.Duo et al (2006) in agreement with our findings reported that there was higher levels of NGF in the keratinocytes of the epidermal basal and spinal layers, and more in dermal infiltrating inflammatory cells in the early atopic dermatitis lesion, compared to the controls. Hodeib A et al (2010) who agree with us said that It has been found that there is significant increase of plasma levels of NGF and NPs in AD patients compared with controls (14).

In this study, we found a positive correlation between the expression of NGF and severity of pruritus in cirrhotic patients. It has been reported that levels of NGF are increased in the serum and skin of $\mathrm{AD}$ patients and serum NGF was proposed to be a marker of disease severity $(\mathbf{1 4}, \mathbf{1 5})$. However, a recent study did not concur with these findings (16). It is known that systemic levels of NGF can be influenced by a variety of physiological, pathophysiological, neuroendocrine factors, such as gender, stress, psychiatric conditions/status, and may very well be under homeostatic and circadian control $(\mathbf{1 7 , 1 8})$.

In sum, here we provide the first indication, to the best of our knowledge, about NGF protein expression in normal healthy skin as well as in cirrhotic patients with and without pruritus. We found differences between these groups with higher expression values in cirrhotic patients with pruritus. Taken collectively, our novel findings suggest a pathophysiological role of these proteins (NGF) in the mechanism of pruritus in cirrhotic patients 


\section{References}

1- Lindor KD, Gershwin ME, Poupon R, Kaplan M, Bergasa NV, Heathcote EJ(2009): American Association for Study of Liver Diseases. Primary biliary cirrhosis. Hepatology.;50(1):291-308 .

2- ones D(2012): Pathogenesis of cholestatic itch: old questions, new

answers, and future opportunities. Hepatology.;56(4):1194-6 .

3- Kremer AE, Feramisco J, Reeh PW, Beuers U, Oude Elferink RP(2014): Receptors, cells and circuits involved in pruritus of systemic

disorders. BiochimBiophysActa.; 1842(7):86992.

4- Oude Elferink RP, Bolier R, Beuers UH(2015):Lysophosphatidic acid and signaling in sensory neurons. BiochimBiophysActa.; 1851(1):61-5.

5- Azevedo R, Takamatsu F, Kondo M, Ferraz M, Mattar R, Cestari S, SalzedasNetto A, Souza P, Pinto W, RezendeFilho F, Oliveira A (2017): Pruritus in cholestasis. Rev Soc Bras Clin Med.;15(1):61-7.

6- Raap U and Kapp A (2010): Neuroimmunological findings in allergic skin diseases. CurrOpin Allergy ClinImmunol 5:419-24

7- Pincelli C, Yaar M (1997): Nerve growth factor: its significance in cutaneous biology.JInvestigDermatolSympProc 2:61-8.

8- Teng $K$ and Hempstead $B$ (2004): Neurotrophins and their receptors: signaling trios in complex biological systems. Cell Mol Life Sci.;61:35-48.

9- Zegarska B, Lelińska A, Tyrakowski T (2006). Clinical and experimental aspects of cutaneous neurogenic inflammation. Pharmacol Rep.;58:13-21.

10- Nockher $W$ and Renz $H$ (2003): Neurotrophins in inflammatory lung diseases: modulators of cell differentiation and neuroimmune interactions. Cytokine Growth Factor Rev; 14: 559-78.
11-Suarez A, Feramisco J, Koo J, Steinhoff M

(2012):

Psychoneuroimmunology

of

Psychological Stress and Atopic

Dermatitis: Pathophysiologic and

Therapeutic Updates. Acta dermatovenereologica:;92(1):7-15

12- Adly M, Assaf H, Nada E, Soliman $M$, Hussein M (2006): Expression of nerve $g$ rowth factor and its high-affinity $\mathrm{r}$ eceptor, tyrosine kinase A proteins, in $\mathrm{t}$ he human scalp skin. $\mathrm{J}$ CutanPathol; 33: 559-568

13- Dou Y, Hagstromer L, Emtestam L. Increased nerve growth factor and its receptors in atopic dermatitis: an immunohistochemical study. Arch Dermatol Res 2006; 298: 31-7.

14-Hodeib A, El-Samad Z, Hanafy H, ElLatief A, El-bendary A, Abu-Raya A: Nerve growth factor, neuropeptides and cutaneous nerves in atopic dermatitis. Indian J Dermatol 2010;55:135-9.

15- Toyoda M, Nakamura M, Makino T, Hino T, Kagoura M, Morohashi $M$ (2002): Nerve growth factor and substance $\mathrm{P}$ are useful plasma markers of disease activity in atopic dermatitis. $\mathrm{Br} J$ Dermatol.; 147:71-9.

16- Schulte-Herbrüggen O, Floster-Holst $R$, von Elstermann $M$, Augustin $M$, Hellweg R: Clinical relevance of nerve growth factor serum levels in patients with atopic dermatitis and psoriasis. IntArch Allergy Immunol. 2007; 144 (3):211-216.

17- Levi-Montalcini R, Dal Toso R, Della Valle F, Skaper SD, Alberta L. Update of the NGF saga. J Neurol Sci. 1995; 130 (2):119-127.

18- Joachim R, Kuhlmei A, Dinh Q, Handjiski B, Fischer T, Peters E: Neuronal plasticity of the brain-skin connection stress-triggered upregulation of neuropeptides in dorsal root ganglia and skin via nerve growth factor-dependent pathways. J Mol Med. 2007; 85 (12):1369-1378. 